\author{
静電浮上リニア駆動機構 \\ 正貝 Ju JIN (KAST) 正員 樋口 俊郎（東京大学、KAST) \\ Direct Electrostatic Levitation and Propulsion \\ Ju JIN, Member (Kanagawa Academy of Science \& Technology) \\ Toshiro HIGUCHI, Member (University of Tokyo, Kanagawa Academy of Science \& Technology)
}

\begin{abstract}
A new type of mechanism featuring "Direct Electrostatic Levitation and Propulsion" (DELP) has been successfully developed. It can directly levitate and drive an object using electrostatic forces. A 3.5-inch diameter aluminum hard disk media has been suspended and transported. In this paper a brief review of the basic principle of the direct electrostatic levitation and propulsion is presented, followed by a description of the structure of the prototype DELP mechanism, including electrode design, position feedback control method for levitation, driving principle and the operational procedure. Experimental results which confirm the completely contactless levitation and propulsion are also presented.
\end{abstract}

キーワード： 静電浮上、静電駆動、HDDメディア、リニアモータ、非接触搬送、真空メカトロニクス

1. まえがき

半導体テバイスやL CDなどの製造工程において，暨埃微 粒子污染が製品の歩留まりを左右する主な原因になっている。 接触・摩擦による帯電およびそれに伴う歴埃微粒子の付着と 発生を抑制するために，ウエハやガラス基板などの非接触搬 送が望まれる。また，新しい材料の創製や表面・界面の研究 において，接触による試料と支持体との間の電子やイオンの 交換を防ぐため，試料を非接触状態で保持・搬送する必要が ある。

現在，ウエハやガラス基板などの搬送㖓置の主流は接触式 である。例えば，半導体製造プロセスにおいて，製造工程間 におけるシリコンウェハの搬送は主にロポットによって行わ れている(1)。シリコンウェハがロボットハンドの上に直接に 置かれているため，接触部がでさてしまう。こうした接触部 には带電が起こり，半導体不良の原因となる鷹埃微粒子が集 まる。また，磁気浮上搬送システムが次世代の般送系しして 期待されているが(2)，磁力によってシリコンウェハなどの半 遒体材料を直接に浮上することは不可能なため, ウェ八を磁 気浮上された載置台に乗せる必要があり、ウェ八と載圈台と の間に接触部ができてしまう。その他の搬送手段として, 空 気浮上般送や超音波浮上搬送があるが(3)（4)，これらは，真 空環境下での使用が不可能である。

本論文は, 超高真空・超清浄空間にも応用可能な非接触搬 送システムの開発の第一歩として, 静電気の力を利用して被 搬送体を宙に浮かせ，周团環境之完全に無接触状態にして般 送する静電浮上リニア駆動機構を提案するとともに,プロト タイプによる3．5インチのア!ミディスクの非接触般送実 験について報告する。

静電気を利用する場合には，次の2つの問題が最も心配さ
れる。(1) 被搬送体が帯電してしまい, 雾囲気中の塺埃微粒 子を被搬送体の表面に集める。(2) 浮上用の静電場が被搬送 体に対して静電破壊などのダメージを与える。

帯電及びそれに伴う應埃の集まりを防ぐ方法として，本研 究の静電浮上リニア駆動機構は，被搬送体の表面電位そのも のを抑制する方法をとつた。具体的には，等面積の浮上用電 極を偶数個配固するとともに，電極には均等に正電圧と負電 圧を印加することにより，被般送体の電位を常にゼロボルト の近くに保つようにした。

静電浮上リニア駆動機構をシリコンウェハの非接触搬送に 応用する場合に, 浮上用の電界によるウエ八表面の菜子の静 電破壊を避けなければならない。次のようにウェハを配㯰す れば、この問題が解決できると考えた。デハイスが加工され るウェハの表面を下向きにし, ウェハの裹面を浮上用電極と 対向させ，浮上用電界がウェ八の表面の素子に影響を及ぼさ ないようにする。その原理は図1に示される.図1において， 浮上用の電極 1 と2 は等面積であり,それぞれに等量異符号 の電圧が印加されている，浮上ギャップと比べ, 電極の面積 が十分に大きく，平行導体板コンデンサと同様に，電極の電 荷もウェハ上に誘導された誘導電荷も内面にのみ分布し， ウェハの表面には電界は存在しない。シリコンウエハ用の观 檽方式静電チャック (5)もこの原理を利用していると言える。

\section{2. 静電浮上リこア駆動機構}

$<2.1>$ 装圈の構成 筆者らが試作した静電浮上リ ニア駆動機構の概略構成を図 2 に示す。機構全体は下部の 6 つの部分から構成される。

（1）浮上兼駆動用電極プレート：浮上力及び駆動力を 発生する。 


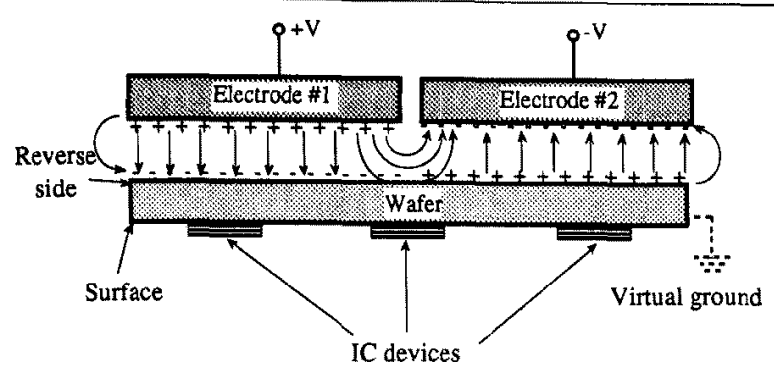

Fig. 1 Electric charges distribution. When the overlapping area of the electrodes and the wafer is large enough compared to the gap: (1) Electric charges distribute only on the inside surface, and the potential of wafer is kept at zero volt; (2) Electric field occurs only at the gap, devices on the wafer surface are not affected by the levitation electric field.

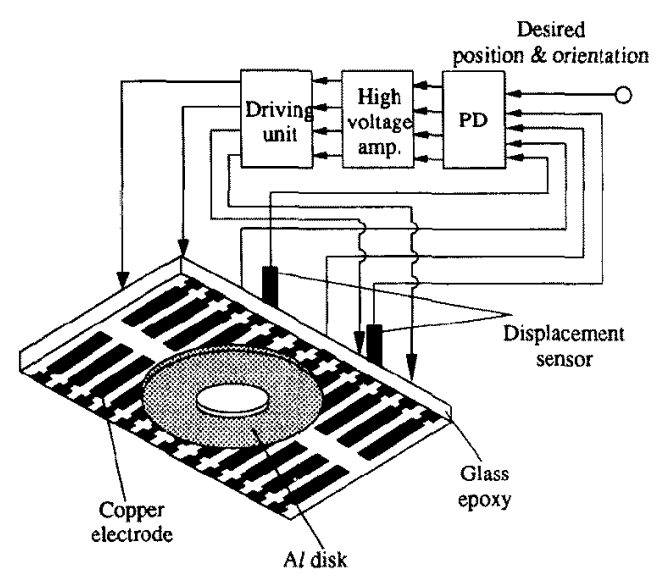

Fig. 2 Schematic of DELP mechanism

(2) アルミディスク：搬送の対象であり,パソコンなど のハードディスクドライブ（HDD）のメディア基板であ る。外径は $95 \mathrm{~mm}$, 内径は $25 \mathrm{~mm}$, 厚さは 0.775 $\mathrm{mm}$, 重さは 14 グラムである。

（3）変位センサ ( 4 個）: 電極とアルミディスクとの ギャップを測定する。

(4) P D コントローラ ( 3 台)：電極への印加電圧を制 御する。

（5）高電压アンプ ( 4 台)：コントローラの出力を增幅 する。

（6）駆動ユニット：電極へ電圧を印加し，そのシーケン スを制御する。

浮上兼駆動用電極プレートの形状と寸法を図 3 に示す。 プレートは絶縁性のカララスエポキシ基板からなり，その上 に幅 $2 \mathrm{~mm}$ の分離帯を挟んで 2 組の銅箔電極ユニットが上 下に形成されている。各電楆ユニットには幅 $4 \mathrm{~mm}$ のスト リッブ状電極が $0.5 \mathrm{~mm}$ の間隔で 26 本形成されている。 電荷の集中を防ぐため，各電極の角部が丸くなっている。

電極プレートには 4 つの変位センサ用の穴が図示の位置 で開いている。4つの変位センサがそれぞれの穴に固定さ れる。

また，浮上および駆動時におけるディスクの横ずれを㧕 えるため, 基板の中央にはディスクの穴に対応した長円形

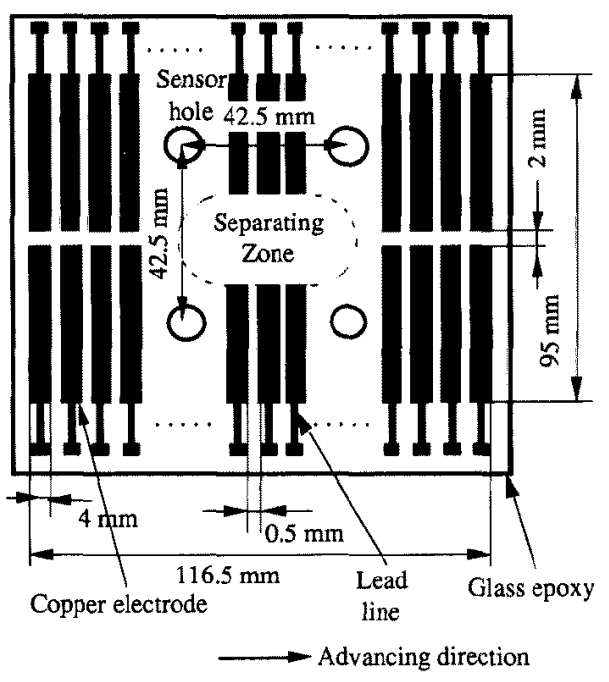

Fig.3 Electrode pattern

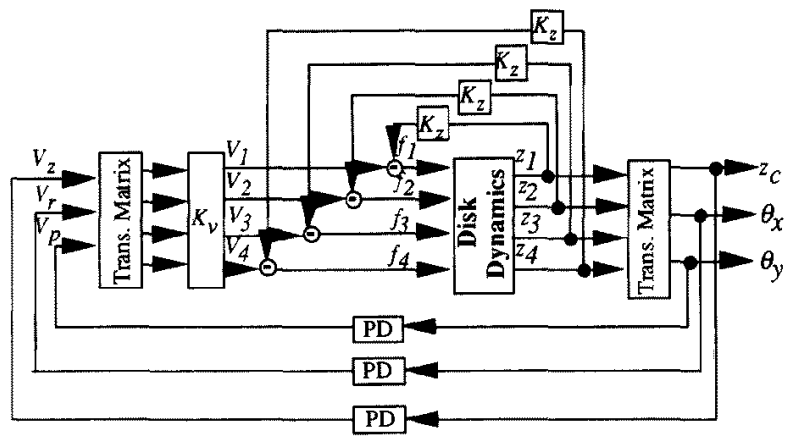

Fig. 4 Integrated control strategy

の無電極ソーンを設沙るとともに，電極部分全体の幅を ディスクの外径と同一にしてある。

$\langle 2 ， 2\rangle$ 静電浮上原理 搬送対象であるアルミ ディスクを浮上して水平に保つには，ディスクの持つ6つ の運動自由度のうち，5つを制御しなければならない。こ の 5 つは, ディスクの水平面内の運動 ( 2 つの自由度), 重 カ方向の運動, ピッチング運動とローリング運動（各 1 自 由度)である。

ディスクの駆動方向と直角する水平面内の並進運動は, 電極の幅がディスクの外径と同じになっているため, 端部 効果によって受動的に拘束されている(6)。駆動方向の並 進運動制御は 2.4 節の駆動原理に述べる。残る 3 つの運 動は図4に示す統合制御法によって能動的に制御される。

統合制御法は浮上体の姿勢および位置を制御する方法 で，原理は次の通りである。

（1）4つの変位センサより 4つの観測点における電極 とディスクとのギャップ $\left(Z_{1}, Z_{2}, Z_{3}, Z_{4}\right)$ を测定し、 それらからディスクの重力方向の位置 $Z_{\mathrm{C}}$, ビッチング角 $\theta_{\mathrm{x}}$ とローリング角 $\theta_{\mathrm{y}}$ を算出する。

（2）位置・姿勢信号をフィードバック信号しして、3 つのPD (比例－微分）コントローラに入力する。PDコ 


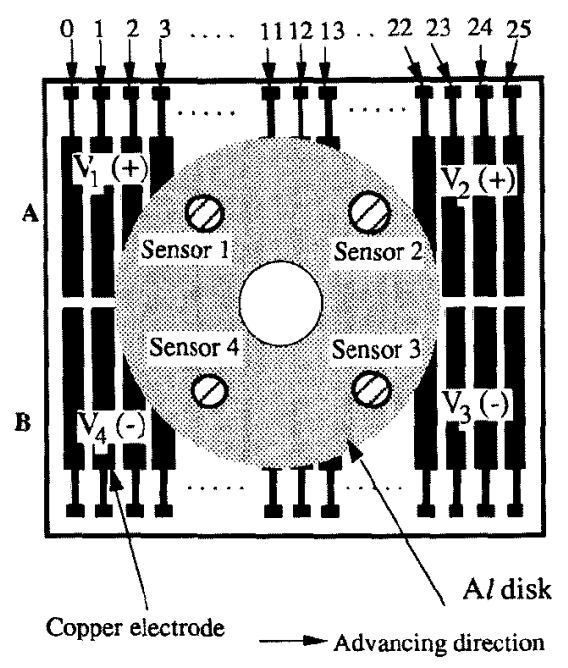

Fig.5 Relative position of electrodes and disk. For the purpose of identification, each strip electrode is considered as an element of a matrix: defining upper electrode unit as row $A$, and the bottom as row $B$, and numbering columns from left to right as 0 to 25. For example, the number of the electrode in row $A$, column 3 is A3.

ントローラは入力信号を目標信号と比較し，その偏差を比 例一微分 $(\mathrm{PD})$ 演算で処理し， $3 \supset$ 電圧信号 $\left(\mathrm{V}_{\mathrm{z}}\right.$, $\mathrm{V}_{\mathrm{r}}, \mathrm{V}_{\mathrm{p}}$ ) を出力する。

(3) 電圧信号 $\left(\mathrm{V}_{\mathrm{z}}, \mathrm{V}_{\mathrm{r}}, \mathrm{V}_{\mathrm{p}}\right)$ とバイアス電圧信号 $\mathrm{V}_{\mathrm{e}}$ とを式（1）のように組み合わ甘，2つの正の制御電 在信号 $\mathrm{V}_{\mathrm{c} 1} 、 \mathrm{~V}_{\mathrm{c} 2}$ と2つの負の制御電圧信号 $\mathrm{V}_{\mathrm{c} 3}, \mathrm{~V}_{\mathrm{c} 4}$ を 作りだし，4台の高電圧アンプへ出力する。

$$
\left\{\begin{array}{l}
V_{c 1}=\left[V_{e}+\left(V_{z} / 4-V_{r} / 2\right)\right] \\
V_{c 2}=\left[V_{e}+\left(V_{z} / 4-V_{p} / 2\right)\right] \\
V_{c 3}=-\left[V_{e}+\left(V_{z} / 4+V_{r} / 2\right)\right] \\
V_{c 4}=-\left[V_{e}+\left(V_{z} / 4+V_{p} / 2\right)\right]
\end{array}\right.
$$

（4）高電压アンプは入力信号を 10000 倍に増幅し, ディスクが目標位固に安定に浮上できるのに必要な $2 つ の$ 正の電压 $\mathrm{V}_{1}, \mathrm{~V}_{2}$ と2つの負の電压 $\mathrm{V}_{3}, \mathrm{~V}_{4}$ を出力する。

$$
\left\{\begin{array}{l}
v_{1}=1000 \times V_{c 1} \\
V_{2}=1000 \times V_{c 2} \\
V_{3}=1000 \times V_{c 3} \\
V_{4}=1000 \times V_{c 4}
\end{array}\right.
$$

（5）正の電圧 $V_{1}, V_{2}$ と負の電圧 $\mathrm{V}_{3}, \mathrm{~V}_{4}$ は, 駆動工 ニットを通して四5のようにディスクの真上にあるスト リップ電極に印加する。つまり，電椣A2〜A11には $\mathrm{V}_{1}, \mathrm{~A} 12 \sim \mathrm{A} 22$ にはV, B $2 \sim \mathrm{B} 11$ にはV 4 , B
12 B 22 にはV 3 を印加する。

そうすると, 電極とディスクの間に静電場が生じ, ディ スクには図 4 に示すような 4 つの静電吸引力（ $\mathrm{f}_{1}, \mathrm{f}_{2}$, $\mathrm{f}_{3}, \mathrm{f}_{4}$ ) が倒き,ディスクを初期位㗨から吸い上げ，目 標位圆にて無接触状態で保持される。

$\langle 2.3\rangle$ 電位ゼロの原理 ディスクが水平に浮上 しているとき, 3つのコントローラの出力 $\left(\mathrm{V}_{\mathrm{z}}, \mathrm{V}_{\mathrm{r}}\right.$, $\mathrm{V}_{\mathrm{p}}$ ) はすべてゼロになり，ストリップ電梗に印加される 電圧の総和はゼロになり,

$$
\sum_{i=1}^{4} V_{i}=0
$$

ディスクの表面電位もゼロボルトになる。

く2.4> 駆動原理 ディスクを浮上した状態て駆 動するには, 静電場を進行方向に治って移動させる必要か゚ ある。本研究の静電浮上リニア駆動機構は, ストリップ電 極に印加する電圧のシーケンスを制御することにより，静 電場を移動させる。

具体的には図 5 に示すように, 進行方向に沿って,ディ スクと重なりがなく,ディスクに最も近い電極 $A 23$ に電 在 $V_{2}, B 23$ に電压 $V_{3}$ を印加する。進行方向の反対側て は,ティスクと重なっている最も外側の電極 A 2 への印加 電圧 $V_{1}, B 2$ への印加電压 $V_{4}$ を切る。それと阁時に, 電 極 $\mathrm{A} 12$ への印加電圧を $\mathrm{V}_{2}$ から $\mathrm{V}_{1} に$, 電極 B 12 亿の印 加電圧を $\mathrm{V}_{3}$ から $\mathrm{V}_{4}$ に切り替える。これで, 静電場が進行 方向に沿って 1 電極分（ピッチ）だけ移動したことにな り,ディスクと静電場との間に相対変位が生じた。

ディスクにはこの相対変位を無くそうとする端部効果に よる水平方向の静電力が動き，ティスクを引つ張り，進行 方向に治って 1 電極分（ピッチ）を移動させる。この過程 を繰り返すことにより,ティスクを浮上した状態で進行方 向に沿って移動することができる。

\section{3.実験結果および考察}

次に静電浮上リニア駆動機構によるHDDメディア用の 3.5インチのアルミディスクの浮上, 般送実験及びその 結果について説明する。

〈3.1> ディスクの初期位置と姿势 ディスク は, 最初に電極プレートの下部 $400 \mu \mathrm{m}$ ところに, 水 平になるように 3 本のマイクロメータヘッドの上に設置さ れる。このとき,ディスクはストリップ状電極 A 2 A 2 2 とB 2 ～B 22 の真下にある。この位置をディスクの耗 送原点とする。

〈3.2〉 ディスクの浮上 次に, ディスクの真上の 電極 A $2 \sim A 22$ と $2 \sim \mathrm{B} 22$ に, 図 5 に示すように電 压 $\mathrm{V}_{1} 、 \mathrm{~V}_{2}, \mathrm{~V}_{3} 、 \mathrm{~V}_{4}$ を印加し、デイスクを初期位置から吸 い上ける。

過大な過度電圧による放電を防ぐため, 電圧印加は 2 段 階に分けて行った。最初に, 電極A 2 A 11 とA 12 2 A 22 には $0.96 \mathrm{kV}$, 電極 B $2 \sim \mathrm{B} 11$ とB $12 \sim \mathrm{B}$ 

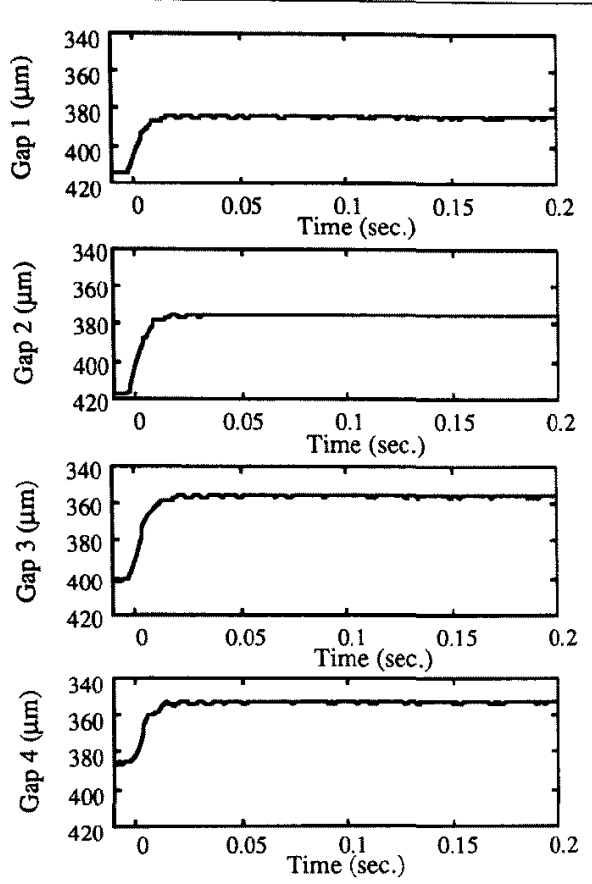

Fig. 6 Gaps change during levitation process

22 にはー0.96 kVのバイアス電圧を印加する。次 に，3つのコントローラのスイッチを同時にオンし，制御 電压を相応する電極に印加する。このとき,ディスクは静 電吸引力によって持占上げられ，因 6 及び図 7 に示す過渡 応答を経て，平衡位置にて安定な浮上状態に入る。

図6にディスクが初期位置から浮上状態に入る過程にお いて，4つの観測点（変位センサが設置されている点）に おける電極とディスクとのギャップ变化を示す。初期状態 では，4つのギャップはそれぞれ $414 ４ ４ 17$, $401 ， 385 \mu \mathrm{m}$ であったが，安定な浮上状態に入る とそれぞれは $384 ， 375 ， 355 ， 352 \mu \mathrm{m} に$ 変 わり，ディスクが宙に浮いていることがよく判る。

また，図6から以下のような事実も判明した。

（1）初期状態において，4つのギャップが同じでない。

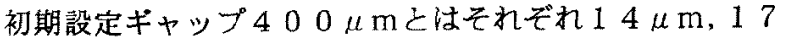
$\mu \mathrm{m}, 1 \mu \mathrm{m},-15 \mu \mathrm{m}$ 差がある。これは, 電極プレ一 卜全体が水平面に対して傾いていることを意味している。

（2）ディスクが浮上状態に入ったとき, 目標の水平浮 上(ギャップ $370 \mu \mathrm{m}$ ) に対して, 約 0.04 度傾いて いる。その原因は電桖プレート全体が傾いているところに ある。

今回の試作機において，電極プレートの水平度を調整す る機構を設置しなかったため，上記の傾きを防げなかっ た。電極プレートの水平度調整機構を設值することによ り，ティスクを水平に浮上することができると思われる。

図 7 に浮上過程における 4 つの印加電圧（ $\mathrm{V}_{1}, \mathrm{~V}_{2}$, $\mathrm{V}_{3}, \mathrm{~V}_{4}$ ) の変化を示す。ディスクが安定な浮上状態に達 したとき，そ扎ぞれは1 $191 \mathrm{~V} １ 109 \mathrm{~V}$, - $1178 \mathrm{~V},-1089 \mathrm{~V}$ である。ディスクが水平に浮
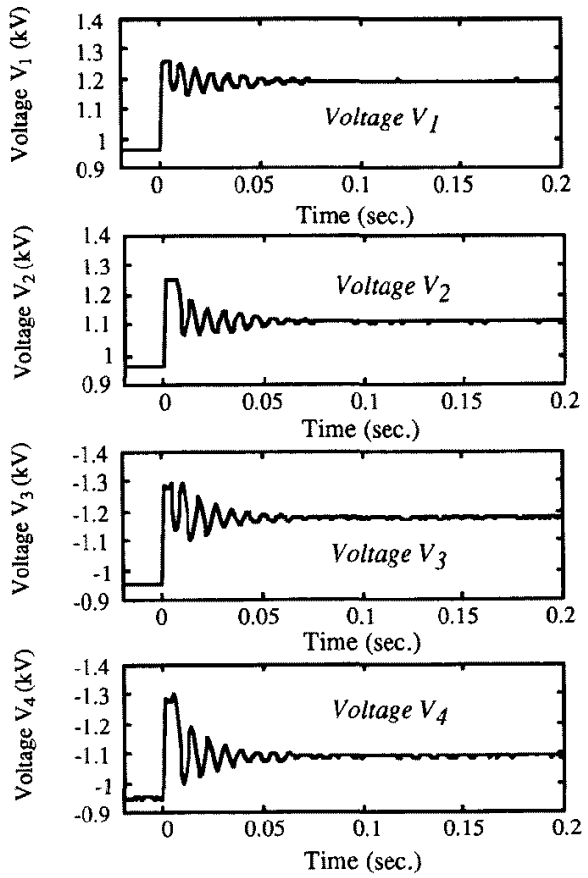

Fig. 7 Voltages change during levitation Process

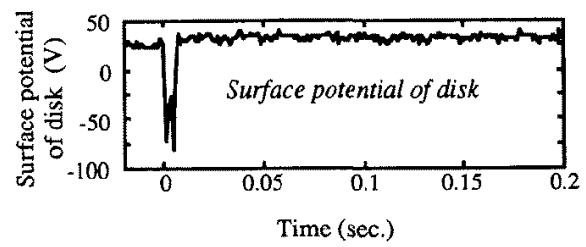

Fig. 8 Surface potential of desk during levitation process 上していれば，4つの電圧の大きさは同じになるが, ティ スクが傾いているため，ばらつきか゚生じた。

図 8 に浮上過程におけるディスクの電位変化を示す。P Dコントローラをオンにしてまもなく,ディスクには最大 マイナス 80 ボルトの電位が現れたが,安定な浮上状態に 入ると, 残留電位が䄪 30 ボルトになった。ディスクが水 平に浮上していれば,残留電位がゼロボルトになるはずだ が、ディスクが傾いているため，上の結果になってしまっ た。この問題も電極プレートを水平に調整することで解決 できると思われる。

帯電による塺埃微粒子の吸着は, 電位がキロポルトの オーダーにならないと発生しないので(7)，30ボルトと いうレベルは大きな障害にはならない。

残留電位によるデバイスの静電破壊の問題だが, 100 V以下では，ほとんどのデバイスが破壊されない(7)。

$\langle 3.3\rangle$ 浮上した状態での般送 ディスクを浮上 したまま般送するため，電極へ電圧を印加するシーケンス を制御する必要がある。本実験装置において，0．65秒 の間隔で電圧を切り替えた場合に,ディスクの運動が最も スームズであった。

ディスクが安定に浮上している時は, 電極A 2 〜 22 とB $2 \sim$ B 22 の真下にある。そこから, 電極 A 23 に電 


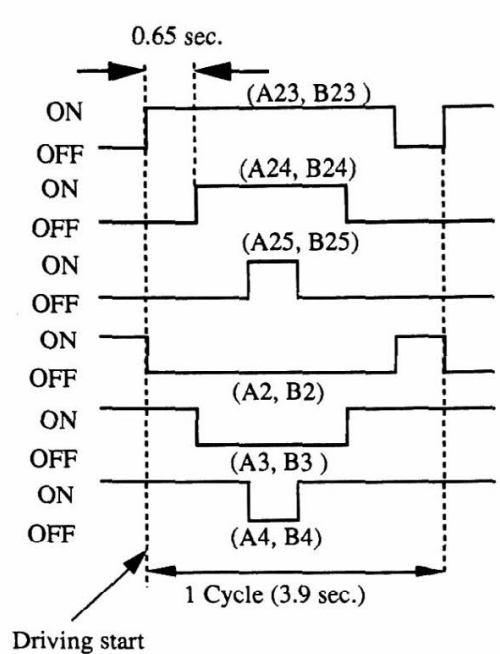

Fig. 9 Voltage-applying sequence

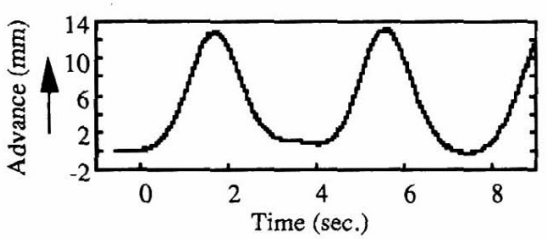

Fig. 10 Disk movement in horizontal direction

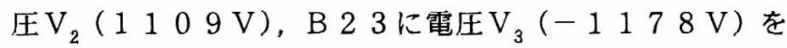
印加する。それと同時に, 電極 $\mathrm{A} 2$ への印加電圧 $\mathrm{V}_{1}$

(1 $1191 \mathrm{~V})$, B 2への印加電圧 $\mathrm{V}_{4}(-1089 \mathrm{~V})$ を切 る。また, 電極 $\Lambda 12$ への印加電圧を $V_{2}$ から $V_{1} に$ に, 電極 B 12 への印加電圧を $\mathrm{V}_{3}$ から $\mathrm{V}_{4}$ に切り替える。

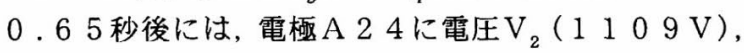
B 24 に電圧 $\mathrm{V}_{3}(-1178 \mathrm{~V})$ を印加する。それと同時 に, 電極 $\mathrm{A} 3$ 个の印加電圧 $\mathrm{V}_{1}\left(\begin{array}{llll}1 & 1 & 9 & 1\end{array}\right.$ V)，B 3 への印 加電圧 $V_{4}(-10089 \mathrm{~V})$ を切る。また, 電極 $\mathrm{A} 13$ ○の 印加電圧を $\mathrm{V}_{2}$ から $\mathrm{V}_{1}$ に, 電極 $\mathrm{B} 13$ への印加電圧を $\mathrm{V}_{3}$ か ら $\mathrm{V}_{4}$ に切り替える。

このように,図 9 のようなタイミングで各列の電極への 電圧の印加シーケンスを制御することにより,ディスクを 3.9 秒の周期で前進後退運動を繰り返させる。

この前進後退運動の様子を図 10 に示す。ディスクが搬 送原点から最大 $13 \mathrm{~mm}$ 移動したことが判る。図1 1 は 搬送中の 4 つの観測点におけるディスクと電極とのギャッ プの変動を示す図であり, 最大 $18 \mu \mathrm{m}$ (ギャップ 3 ) の 変動があることが判明した。般送中のディスク表面電位の 変化は図 12 に示され, 約 $10 \mathrm{~V}$ 変化が見られた。 図 13 に搬送中のディスクの様子を示す。

\section{4.結論および今後の課題}

本論文において,筆者らが提案した竫電浮上リニア駆動 機構の構造, 動作原理について説明し, 試作したプロトタ
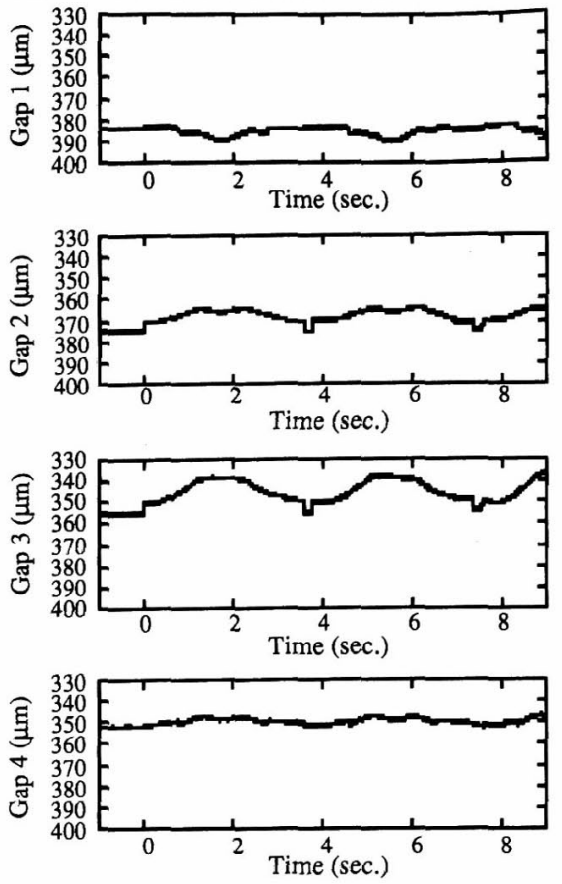

Fig. 11 Gaps change during transportation

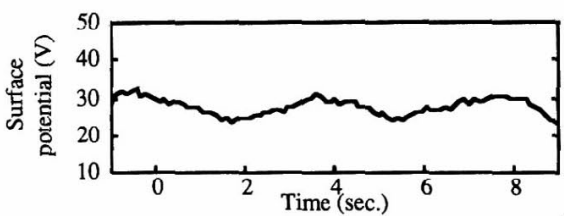

Fig. 12 Surface potential of disk during transportation

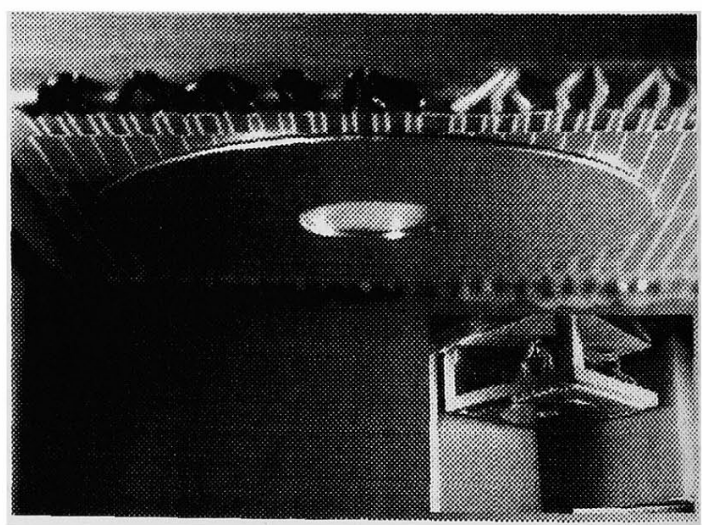

Fig. 13 Photograph of Prototype DELP

イプによる 3.5 インチのアルミディスクの非接触搬送を 実験で確認した。これで, 非磁性材料を非接触状態で搬送 する一つの方法を示した。以下に, 静電浮上リこア駆動機 構の特長と欠点を示した後, 実用化に当たって解決すべき 問題点を明らかにする。

$<4.1>$ 静電浮上駆動機構の特長 磁気浮上式般 送システムと比べ, 静電浮上駆動機構は下記の特長を有す る。

（1）磁気力は磁性材料しか直接に浮上することができ 
ないが, 静電力は金属をはじめ, 半導体, 誘電体など広範 な物体を直接に浮上することができる。半導体と誘電体の 場合には，伝導電子の移動スピードがある程度早ければ， 静電浮上の立場から見ると導体とみなしても差し支えな い。

（2）磁気浮上系には, 通常アンペアオーダの電流がコ イルを流れるが, 静電浮上系においては, 電流のオーダは ミリアンペアである。従って, 磁気浮上と比べ, 静電浮上 による発熱が非常に少なく, 真空環境にもっと適してい る。

（3）本研究の静電浮上リニア駆動機構は，被搬送体の 表面に電極パターンを形成する必要がなく,そのままの状 態で非接触保持して搬送できる。

$\langle 4.2\rangle$ 静電浮上駆動機構の欠点 磁気浮上シス テムと比べ, 静電浮上機構は次のような欠点を持ってい る。

（1）浮上剛性が低く, 外部振動に弱い。静電浮上の場 合に, 得られる最大吸引力は電極と浮上体とのギャップに 存在する気体の絶縁強度によって決められ, 気体の絶縁強 度は種類と圧力によって制限されている。例えば, 大気中 で, 空気の絶縁強度は約 $3 \mathrm{~V} / \mu \mathrm{m}$ で, 得られる最大吸引 力は約 $40 \mathrm{~N} / \mathrm{m}^{2}$ である。

（2）高電圧を使用しているため, 安全上に十分な注意 を払わなければならない。

(3) 真空度の低い環境 (10 ${ }^{-4}$ Torr 以下) (8) では, 放 電が起こりやすく, 浮上に必要な力が得られなく, 静電浮 上機構は動作しにくくなる。

$\langle 4.3\rangle$ 実用化にあたる課題 静電浮上駆動機構 を実用レベルに仕上げるために, 次のような問題を解決し なければならない。

（1）被搬送体に残留電位が残らないような電圧制御方 法を開発する。

（2）半導体製造プロセスにおけるシリコンウェハの般 送に使われる場合, ウェハの表面が下に向いているため, 現存の多くのプロセス装置との適合性が低い。装置内に搬 入した後,ウェハの表面を上向きにするような転向装置を 設置しなければならない。

（3）長距離の搬送に当たって, 多数の変位センサを配 置しなければならず, コストが高くなってしまう。安価な センサの開発が必要である。

今後はこれらの課題を 1 つずつ解決していく予定であ る。

最後に, 本研究に協力していただいた（株）三菱マテリ アル中央研究所の金本学様に深く感謝いたします。

(平成 7 年 4 月 25 日受付, 同 7 年 9 月 5 日再受付)

$$
\text { 文献 }
$$

（1）玉川, 松井, ほか 3 名, ”超清浄・超高真主空間が拓く 未来”, ULVAC TECHNICAL JOURNAL, No. 39, pp.79-
83, 1992.

(2) M. Ota, S. Andoh and H. Inoue, "Mag-Lev semiconductor wafer transporter for ultra high vacuum environment", Proceedings of the 2nd International Symposium on Magnetic Bearings", pp. 109-114, 1990.

(3) ソーラーリサーチ研究所カタログ, ”フロートチャッ ク”, 1989 年。

（4）日経産業新聞,” 5 キロの基板触れず浮揚”, 199 5 年 3 月 13 日。

(5) G. A. Wardly, "Electrostatic wafer chuck for electron beam microfabrication", Review of Scientific. Instruments, Vol. 44, No. 10, pp.1506-1509, 1973.

(6) S. J. Woo, J. Jin and T. Higuchi, "Lateral response of electrostatic suspension system", 1995 National Conference Record of IEEJ, 1995.

(7) 辻, ” L S I 製造における静電気問題と対策”, 静電気 学会誌, Vol. 19, No. 1, pp. 28-34, 1995.

（8）静電気学会, ”静電気ハンドブック”, オーム社, 1981.

(9) J. Jin, T. Higuchi and M. Kanemoto, "Electrostatic levitator for hard disk media", IEEE Transactions on Industrial Electronics, Vol. 42, No. 5, pp. 467-473, 1995.

(10) J. Jin, T. Higuchi and M. Kanemoto, "Electrostatic silicon wafer suspension", Proceedings of the 4th International Symposium on Magnetic Bearings", pp.343-348, 1994.

(11) J. Jin and T. Higuchi, "Direct electrostatic levitation and propulsion", Proceedings of the 34th SICE Annual Conference, pp. 1437-1441, 1995.

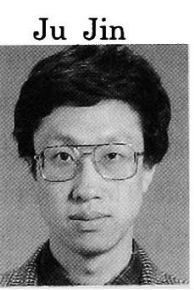
（正員）1964年12月生まれ。85 年中 国西安交通大学パワー・エンジンニアリング (Power Engineering) 系卒業。89 年長岡 科学技術大学機械システム専攻修士課程修 了。9 2 年東京大学精密機械工学専攻博士課 程修了。工学博士号取得。同年, (財) 神奈 川科学技術アカデミー樋口「極限メカトロニクス」プロジェ ク研究員, 現在に至る。静電浮上駆動機構, 磁気浮上駆動機 構の研究開発に従事。IEEE, 計測自動制御学会, 静電気学 会などの会員。

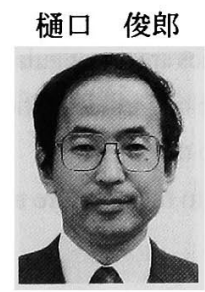

（正員） 1950 年 2 月生まれ。 72 年東京 大学精密機械工学科卒業。7 7 年同博士課 程修了，工学博士号取得。同年，東京大学 生産技術研究所講師, 78 年同助教授。9 1 年東京大学精密機械工学科教授。93 年 (財) 神奈川科学技術アカデミー樋口「極限 メカトロニクス」プロジェクトリーダー康 任。85 年工作機械技術振興賞, 88 年精 密工学会賞, 91 年日本ロボット学会技術賞。磁気軸受, 静 電浮上駆動機構, 静電モ一夕, 精密加工, 圧電素子を利用乙 た精密位置決めなど，メカトロニクスに関する研究に従事。 I E E E, 精密工学会, 計測自動制御学会などの会員。 